\title{
VAMMAISET JA PITKÄAIKAISSAIRAAT OPPISOPIMUSKOULUTUKSEN AVULLA AVOIMILLE TYÖMARKKINOILLE ${ }^{1}$
}

\author{
Marja Irjala: KT, ekonomi, järjestöneuvos \\ marja.irjala@gmail.com \\ Janus vol. 26 (2) 2018, 156-163
}

JOHDANTO

Ulkopuolisuus, marginalisoituminen ja osattomuus koulutuksesta ja työelämästä ovat maassamme laajamittainen sosiaalipoliittinen ja kansantaloudellinen ongelma. Tämä siitä huolimatta, että kansalaisilla ei ole koskaan mennyt niin hyvin kuin 2010-luvun alussa ja valtaosa väestöstä on tyytyväisiä kokemaansa elämänlaatuun (Saari 2015, 11). Samalla kun palkkatyöstä on tullut modernissa valtiossa työikäisten tärkein keino hankkia elantonsa ja toisaalta yhteiskunnallisen järjestyksen keskeinen ylläpitäjä, huono-osaisimpien ryhmään on yhä yleisemmin alettu luokittelemaan erityisesti työstä ja koulutuksesta syrjäytyneet (Eriksson 2008, 12; Silvennoinen 2002, 9). Työllisyyspoliittisessa keskustelussa ei juurikaan ole tullut esille, että meillä on tuhansia työkykyisiä tai osatyökykyisiä vammaisia tai heihin verrattavia pitkäaikaissairaita henkilöitä, joille oppisopimuskoulutus voisi osaltaan tarjota mahdollisuuden osallisuuteen yhteiskunnassa. Saksan työmarkkinatilanne on ollut viime vuosien ajan päinvastainen kuin Suomessa. Erityisesti maan suurteollisuus on kärsinyt jatkuvasta työvoimapulasta, mikä on helpottanut myös vaikeimmin työllistyvien ryhmien pääsyä avoimille työmark- kinoille. Lisäksi Saksassa työnantajien lakisääteinen velvoite työllistää määrätty kiintiö vammaisia antaa sikäläisille vammaisille ja muille erityisopiskelijoille paremmat mahdollisuudet kuin Suomessa työllistyä kokopäivätyöhön aivan tavanomaisille työpaikoille.

Ammatillisen koulutuksen reformia koskevassa keskustelussa työpaikalla ja samanaikaisesti teoriaopiskeluna suoritettava oppisopimuskoulutus ja erityisesti sen saksainen malli ovat olleet Suomessa ajankohtainen puheenaihe. Ammatillinen koulutus, myös erityisopiskelijoille tarkoitettu, on viime vuosikymmeninä rakentunut Suomessa laitosmaiseksi järjestelmäksi, jota täydentävät erilaiset työssä oppimisen jaksot. Koulutuksen menetelmiin kuuluvan oppisopimuskoulutuksen kehittämistyö on sen sijaan ollut aikojen kuluessa vaihtelevaa. (Leino 2011, 18.) Väitöstyölläni halusin edistää erityisesti suomalaisten vammaisten ja heihin verrattavien pitkäaikaissairaiden työllistymismahdollisuuksia normaaleille työpaikoille. Yli 20 vuotta kestänyt työurani lastensuojelu- ja vammaisjärjestö Nuorten Ystävät ry:n pääsihteerinä oli vahvistanut käsitystäni, että vammaisten ja osatyökykyisten osallisuus työelämässä on merkittävästi 
heikentynyt niistä ajoista, kun viittomakieliset kuurot vanhempani ja koko heidän laaja koulutoveri- ja ystäväpiirinsä työskentelivät aivan normaaleilla työmarkkinoilla hyvinkin erilaisissa tehtävissä ja eri aloilla, yhdenvertaisina muiden kanssa. Nuorten Ystävät -järjestö on koko 110-vuotisen historiansa ajan panostanut ja ollut edelläkävijä juuri tämän asian edistämisessä. Työurani päätyttyä minulle tarjoutui mahdollisuus jatkaa aiemmin kesken jääneitä kasvatustieteen opintojani, ensin Tampereen yliopiston ammattikasvatuksen maisteriohjelmassa vuonna 2013 ja sen jälkeen väitöskirjaan Oulun yliopistossa.

\section{VAMMAISTEN OPPISOPIMUSKOULUTUS Suomessa ja Saksassa}

Ammatillisen tutkinnon suorittaminen oppisopimuskoulutuksena on Suomessa ollut jo pitkään nimellisesti mahdollista useilla koulutuksen asteilla ja aloilla. Menetelmän käyttäminen erityisopiskelijoiden koulutuksessa on kuitenkin ollut todella vähäistä. (Leino 2011, 94, 96.) Heidän osaltaan se on ollut lähinnä pienimuotoista kokeilu- ja kehittämistoimintaa, jota ovat ylläpitäneet muutamat ammatilliset erityisoppilaitokset ja oppisopimustoimistot yhteistyössä sosiaalialan järjestöjen kanssa. Saksassa oppisopimuskoulutusta on kehitetty keskeytyksettä niin taloudellisesti hyvinä kuin huonoinakin aikoina yhteistyössä työ- ja elinkeinoelämän kanssa jo vuosisatojen ajan (OECD 2010, 5-6). Menetelmä toimii koko ammatillisen koulutusjärjestelmän perustana ja kattaa yli 80 prosenttia maan ammatillisesta koulutuksesta, kaikkien opiskelijoiden osalta. Elinkeinoelämä eli teollisuus-, kauppa- ja pienteollisuuskamarit sekä yritykset ja niiden työvoimatarpeet toimivat koulutuksen vetureina. Koulutusohjelmissa olevia ammattitutkintoja on satoja ja opiskelijat voivat päätyä tuhansiin eri ammattivaihtoehtoihin. Yritykset maksavat vuosittain kamarille osuusmaksun koulutuksen ylläpitämisestä. $\mathrm{Ne}$ sitoutuvat näin toimintaan panostamalla järjestelmän ylläpitoon myös taloudellisesti. Yritys ja oppisopimusopiskelija solmivat koulutussopimuksen. (Handelskammer Hamburg 2014a.) Näin ollen sikäläisten yritysten ja muiden työnantajayhteisöjen voidaan katsoa toimivan siellä koulutuspalvelujen tuottajina sanan varsinaisessa merkityksessä (vrt. Norontaus 2016).

Oppisopimuskoulutus on sekä Suomessa että Saksassa keskimäärin kolme vuotta kestävä, suurimmaksi osaksi työpaikalla ja työtehtävinä suoritettava ammatillisen koulutuksen menetelmä. Työpaikalle nimetään opintojen ohjaamisesta vastaava työpaikkakouluttaja. Opiskelija suorittaa samanaikaisesti määrätyn määrän teoriaopintoja ammatillisessa oppilaitoksessa. Saksassa työpaikalla oppija on selkeästi opiskelija eli saa kuukausittaisen koulutuskorvauksen yritykseltä. Työmarkkinajärjestöt sopivat siellä vuosittain alakohtaisten työehtosopimusneuvottelujensa yhteydessä opiskelujen edetessä korotettavasta korvauksesta. Suomessa taas koko toiminnan organisoinnista vastaavat julkishallinnolliset oppisopimustoimistot ja -keskukset. Opiskelija on työsuhteessa, saa yleensä minimipalkkaa vastaavaa palkkaa ja on työlainsäädännön piirissä. Yhteiskunta korvaa osan, vammaisten opiskelijoiden osalta merkittävän osan, kuluista työnanta- 
jalle. Vammaiset opiskelijat tarvitsevat usein myös muuta henkilökohtaista tukea opiskelussaan, mihin tarpeeseen on vastattu, sekä Suomessa että Saksassa, palkkaamalla heille yleensä ryhmäkohtainen ammatillinen työhönvalmentaja. Hän ohjaa ja tukee opiskelijaa sekä työpaikalla että tarvittaessa myös teoriatunneilla. (Handelskammer Hamburg 2014a, 14; Handelskammer Hamburg 2014b; Hensen-Reifgens \& HippachSchneider 2014, 13; Opetushallitus 2017.)

Haastattelin eri tavoin vammaisia ja pitkäaikaissairaita Suomessa ja Saksassa. Tein väitöskirjaani varten kuusi haastattelumatkaa Pohjois-Saksaan ja kahdeksan eri puolille Pohjois- ja Etelä-Suomea. Tapasin yhteensä 30 suomalaisen ja saksalaisen oppisopimuskoulutuksen avulla valmistunutta tai valmistumassa olevaa vammaista, pitkäaikaissairasta tai osatyökykyistä henkilöä molemmissa maissa. Suurin osa heistä oli nuoria aikuisia. Haastatellut edustivat useita eri vammais- ja pitkäaikaissairauksien ryhmiä. Kaikkien toimintakyky ja soveltuvuus oppisopimuskoulutukseen oli monipuolisesti arvioitu ennen koulutukseen hyväksymistä. Useimmat suomalaiset olivat suorittaneet ammatillisen perustutkinnon paikallisen oppisopimuskeskuksen ja ammatillisen erityisoppilaitoksen yhteistyönä ylläpitämässä kokeilu- ja kehittämishankkeessa, niin sanottuna tuettuna oppisopimuskoulutuksena. Saksalaiset olivat suorittaneet koulutuksensa normaaleissa ammatillisen koulutuksen järjestelmissä tai suomalaisia ammatillisia erityisoppilaitoksia vastaavien $B B W$ Berufsbildungswerk-oppilaitosten organisoimina ja niiden tarjoamien tukipalvelujen avulla.
Halusin saada tietoa oppisopimuskoulutuksen suorittaneilta tai koulutuksen loppuvaiheessa olevilta siitä, miten he kokivat koulutuksen vaikuttaneen heidän osallisuuteensa ja arjen kokemuksiinsa ylipäätänsä. Esiymmärrykseni oli, että oppisopimuskoulutus riittävillä tukipanostuksilla varustettuna on hyvä väylä vammaisille osallisuuteen yhteiskunnassa. Tätä osoittivat aiemmin tuetusta oppisopimuskoulutuksesta kirjoittamani pro gradu -tutkielman tulokset (Irjala 2014). Haastattelun teemat olin toimittanut osanottajille etukäteen mietittäviksi. Haastattelut suoritin neljällä eri kielellä - suomeksi ja saksaksi sekä suomalaisella ja saksalaisella viittomakielellä, sillä osallistujista yhdeksän oli viittomakielisiä kuuroja. Suomalaisten kuurojen kohdalla en viittomakielen taitoisena ja entisenä tulkkina tarvinnut tulkkia. Saksassa minulla oli paikalla avustaja, jonka läsnäolo oli viittomakielisissä haastatteluissa välttämätön. Toisin kuin usein oletetaan, kussakin maassa käytettävä tavanomainen viittomakieli ei ole kansainvälinen kieli. Kaikki tapaamani pitivät aihettani tärkeänä ja olivat siitä innostuneita. Saamani aineiston runsaus, monipuolisuus ja kiinnostavuus yllättivät minut täysin.

\section{SUOMALAISEN OPPISOPIMUSKOULUTUKSEN HEIKKOUDET JA MUITA TUTKIMUSTULOKSIA}

Vammaisten ammatilliseen koulutukseen ja työllistymiseen liittyvä merkittävä ongelma Suomessa on näennäiskehittäminen eli kehittämis- ja kokeilutoiminta, josta konkretisoituu todella vähän pysyvään käytäntöön (vrt. Brunila 2013, 236-238, 242-244). Muun muassa riittävillä tukipalveluilla vahvistettu oppisopimuskoulutus on 
projektiluontoista ja sen jatkuminen vuodesta toiseen epävarmaa. Vammaisten oikeuksista koulutukseen ja työhön on julkaistu maassamme lukuisa määrä raportteja ja periaatepäätöksiä. Sosiaali- ja terveysministeriön vammaispoliittinen ohjelma vuosille 2010-2015 (Sosiaali- ja terveysministeriö 2010) on kuvaava esimerkki ohjelmista, projekteista ja kehittämishankkeista, joiden konkreettiset tulokset jäävät pimentoon. Kyseisessä ohjelmassa todetaan, että "työhön osallistumisen mahdollisuudet tulee turvata kaikille" ja nimenomaan "avoimille työmarkkinoille, palkkasuhteiseen työhön".

Saksassa aloitettiin Suomen tuettua oppisopimuskoulutusta vastaavan Assistierte Ausbildung -menetelmän kokeilu Baden-Württembergin seudulla vuonna 2004. Kokeilusta saatujen hyvien tulosten perusteella toiminta tuli lakisääteiseksi koko liittotasavallan alueella toukokuussa 2015. (Lippegaus-Grünau 2014, 6.) Menetelmän painopiste oli aluksi vaikeimmin työllistyvien, syrjäytymisvaarassa olevien nuorten kouluttamisessa mutta sitä on nyt laajennettu myös vammaisten ja pitkäaikaissairaiden ammatilliseen koulutukseen. Suomessa vastaavaa toimintaa on kehitetty vuodesta 2007 ja pidetty yllä pienimuotoisesti ja lähinnä kolmannen sektorin saamien niukkojen, tilapäisten tukien turvin vuodesta 2009 alkaen. Tuetusta oppisopimuskoulutuksesta olisi helppo luoda lakisääteinen malli vammaisille. Malli palvelisi monien muidenkin vaikeimmin työllistyvien ryhmien koulutusta ja työllistymistä, muun muassa osana ajankohtaista maahanmuuttajien kotouttamista.
Tutkimustulokseni osoittavat, että oppisopimuskoulutus estää selkeästi syrjäytymistä. Se antaa vammaisille ja osatyökykyisille kokemuksen mielekkäästä elämästä, osallisuudesta ja arvokkuudesta. Suurin osa haastatelluista oli sijoittunut koulutuksen jälkeen työsuhteeseen joko kokopäivä- tai erityisesti Suomessa osa-aikatyöhön. Saksalaisista haastatelluista seitsemän työskenteli auto- tai lentokonetehtaalla normaalissa kokopäivätyössä. Muutamat työskentelivät toimistotehtävissä rahoitus- ja vakuutusalalla, tutkimusinstituutissa sekä vammaisjärjestön palveluksessa. Käsi- ja pienteollisuuden tehtäviin oli kouluttautumassa yksi oppisopimuskoulutettava. Suomalaisista haastatelluista useimmat työskentelivät siivous- ja puhdistusalalla (toimitilahuoltajat), muut maatalous- ja puutarhatehtävissä, käsi- ja pienteollisuusalalla sekä sosiaali- ja terveysalalla ja yksi keittiö- ja catering-alalla. Yksi suomalainen oli jäänyt koulutuksen jälkeen työkyvyttömyyseläkkeelle ja toinen oli työttömänä työnhakijana.

Haastatelluista suurimman osan elämä näyttäytyi tyydyttävänä, "hyvänä elämänä”, jos ja kun heillä oli mahdollisuus tavoitella parhaita, inhimillisesti ottaen itselleen mahdollisia mahdollisuuksia elämässään (Vehmas 2005, 172-174). Saksalaisten haastateltujen joukossa oli niin vaikeavammaisia, että oppisopimuskoulutuksen merkitys valaistui minulle jo sen vuoksi. Vaikuttavinta oli tavata auto- ja lentokonetehtaiden "muurinmurtajia". He olivat ensin läpäisseet työpaikan asennemuurin, vammaiseen työnhakijaan epäilevät tai kielteisetkin asenteet, ja olivat sen jälkeen saaneet tai saamassa työkavereikseen muita vertaisiaan. Työstään yl- 
peä, työpaikkansa ensimmäinen kuuro suurella lentokonetehtaalla oli "vetänyt perässään" jo 20 muuta viittomakielistä samaan työyhteisöön.

Kaiken kaikkiaan haastattelemani nuoret vammaiset niin Suomessa kuin Saksassakin halusivat elää niin, että heidän vammaisuuteensa tai sairauteensa ei kiinnitettäisi sen kummempaa huomiota. Pikemminkin he toivoivat, että työnantajat katsoisivat heidän vammojensa tai sairauksiensa "taakse" eli vahvuuksiinsa ja voimavaroihinsa. Työkansalaisuus tarjosi heille suunnitelmia uralla etenemisestä, lisäkoulutuksesta tai yleensä hyvästä, tasapainoisesta, ihan "normaalista" elämästä. (vrt. Sihvola 2004, 64, 214.) He toivoivat saavansa tukea, hoivaa ja turvaa mutta - vain tarvitessaan. He osoittautuivat peräänantamattomiksi ja sisukkaiksi jo peruskoulun aikana. Ennen oppisopimuskoulutusta ja sen aikana tutkimuksen osanottajat olivat saaneet tukea perheeltään, koulutuksen tukipalveluilta ja vertaisiltaan. Heillä oli ystäviä ja muita sosiaalisia verkostoja. Monet olivat selkeästi valoisia onnistujia. Työ on heille nyt tärkeä arjen jäsentäjä, tuo tyydyttävän toimeentulon sekä mahdollisuuden tulevaisuuden myönteiseen suunnitteluun.

Muutamat tutkimukseen osallistuneet sekä Suomessa että Saksassa olivat sijoittuneet oppisopimuskoulutuksen jälkeen palkattomaan niin kutsuttuun avotyöhön normaaleille työpaikoille tai vammaisten työkeskuksiin. Avotyön järjestelmä on räikeä esimerkki kansainvälisten ja kansallisten sopimusten sekä säädösten rikkomisesta. Se tarkoittaa henkilön työskentelyä esimerkiksi kunnan toimintakeskuksessa tai sen määrittämällä normaalilla työpaikalla ilman palkkaa ja työlakien määrittämiä muita työsuhde-etuja. Korvaus on yleensä Suomessa 0-12 euroa päivältä ja Saksassa 200-300 euroa kuukaudessa verottomana ahkeruus- tai toimintarahana. Avotyö osoittautui pahimmaksi vammaisten oikeuksia loukkaavaksi rakenteelliseksi riippuvuusloukuksi molemmissa maissa. Siinä on selkeästi kyse filosofi Iris Marion Youngin (1990, 3-12) mukaisesta sorron pahimmasta muodosta eli marginalisoinnista, joka tapahtuu näennäisesti hyvää tarkoittavien järjestelmien kautta. Saksassa käydäänkin parhaillaan keskustelua vammaisten työkeskusten siirtämisestä osaksi normaalia tuotanto- ja elinkeinoelämää.

\section{MIKÄ NEUVOKSI?}

Jotta erityisopiskelijoiden oppisopimuskoulutus mahdollistuisi myös Suomessa nykyistä laajemmin ja pysyvillä rakenteilla, järjestelmään on turvattava ennen kaikkea riittävät tukipalvelut ja niiden pysyvä rahoitus. Saksassa lainsäädäntö ja sen nopea reagointi ajankohtaisiin ongelmiin osoittautui vahvaksi muutosvoimaksi yhdenvertaisen työkansalaisuuden edistämisessä. Useimmat haastateltavat kokivat saaneensa työhönvalmentajaltaan paljon tukea ja pitivät tämän panosta erityisen tärkeänä tekijänä koulutuksensa onnistumiselle. Avoimille työmarkkinoille työllistyneet olivat selkeästi ylpeitä ja onnellisia siitä, että olivat saavuttaneet jotakin sellaista, mikä ei ollut heille eikä muillekaan kaltaisilleen itsestään selvää. $\mathrm{He}$ olivat päässeet asennemuurien läpi ja useat vetäneet perässään muita vammaisia samaan työpaikkaan. Tämä tuli esille 
etenkin saksalaisilla työpaikoilla. Samaa onnea ja ylpeyttä oli kuitenkin havaittavissa myös suomalaisissa tavanomaisille työpaikoille työllistyneissä, riippumatta siitä, oliko kyse kokopäivä- tai osa-aikatyöstä.

Väitöstyöni tulosten perusteella olen nyt vakuuttunut siitä, että suomalaisten vammaisten ja osatyökykyisten pääsy avoimille työmarkkinoille ei toteudu ilman, että saamme aikaan kaksi merkittävää uudistusta maassamme. Ensimmäinen, ja kiireellisin, on kiintiölaki (Sozialgesetzbuch IX \ 71) Saksan malliin, jonka valtiovalta ja ammattijärjestöt voisivat hyväksyä. Lain mukaan yritysten ja yhteisöjen olisi palkattava myös vammaisen tai osatyökykyisen statuksen omaavia työnhakijoita määrätty määrä työyhteisöönsä. Saksassa se tarkoittaa, että vähintään 20 työntekijää työllistävän yhteisön on työllistettävä vähintään yksi vammainen eli viisi prosenttia työvoiman kokonaismäärästä. Mikäli työnantaja ei täytä kyseistä lainkohtaa, se joutuu maksamaan kuukausittaista sakkomaksua integraatiovirastolle vammaisten työkeskusten ylläpitämiseen.

Toinen välttämätön uudistus molemmissa maissa olisi, että myös työ- ja elinkeinoelämä ottaisi käsittelyynsä vammaisten avotyön ja toimintakeskusten tulevaisuuden. Vammaisten oikeuksien sopimus ratifioitiin Suomessa keväällä 2016 ja Saksassa vuonna 2009. Jo noiden ratifiointien sekä YK:n ihmisoikeuksien sopimuksen sekä molemmissa maissa voimassa olevien yhdenvertaisuuslakien perusteella avotyön rooli olisi otettava kiireelliseen käsittelyyn. Meillä olisi myös avattava julkinen keskustelu siitä, miten vammaisten avotyössä suorittamasta työpanoksesta voidaan tehdä osa maan tuotantoelämää. Pienikin työpanos on työpanos, josta on suoritettava asianmukainen korvaus. Sitä ei ole suinkaan 0-12 euron ahkeruusraha, toimintaraha, tai saksalaisittain taskuraha (Taschengeld), pitkältä työpäivältä puutarhalla tai tehtaan alihankintatyötä suorittavassa toimintakeskuksessa.

\section{LOPUKSI}

Väitöskirjani teoriaosuuden eräänä lähtökohtana oli amerikkalaisen filosofin John Rawlsin (1986/1988) oikeudenmukaisuusteoria, joka noudattaa pitkälti sitä, miten itse olin ajatellut työtä aloittaessani: meillä ei ole varaa jättää ketään ulkopuoliseksi. Jokaisella ihmisellä on oma inhimillinen arvonsa, oikeus arvokkaaseen elämään ja täyteen osallisuuteen yhteiskunnassa. Eräs suomalainen tutkimuksen lievästi kehitysvammainen osallistuja kiertää todennäköisesti vieläkin työttömänä työnhakijana avotyön ja koulutuksen kehää pääsemättä kiinni mihinkään työyhteisöön. Hän ihmettelikin, eikö kukaan työnantaja tarvitse hänen laistaan urheilua harrastavaa, parhaassa työiässä olevaa monen ammattitutkinnon suorittanutta miestä. Häneenkin pätee se, mitä John Rawlsin ajatuksia pitkälti seuraava filosofi Richard Sennett kirjoittaa:

Tämä kaikki (osattomuus) vie ihmisiltä mahdollisuuden kokea itsensä merkityksellisiksi, tuntea että joku välittää ja tarvitsee. ... Ihmisen luonne syöpyy, kuluu sisältäpäin; kysymykseen 'kuka tarvitsee minua?' ei ole välitöntä vastausta. Sen kuitenkin tiedän, että (työn) järjestys joka ei anna 
ihmisille mitään syvällistä syytä huolehtia toinen toisestaan, ei voi kauaa säilyttää oikeutustaan. (Sennett 1998/2002, 159, 163.)

\section{VIITE}

${ }^{1}$ Puheenvuoro perustuu Oulun yliopistossa 22.9.2017 tarkastetun kasvatustieteen väitöskirjan lectio praecursoriaan.

\section{KIRJALLISUUS}

Brunila, Kristiina (2013) Tavoitteena mielentilan oikea hallinta - Yhteisvastuusta yksilölliseksi taloustalkoohenkiseksi vastuuksi. Teoksessa Kristiina Brunila, Katariina Hakala, Elina Lahelma \& Antti Teittinen (toim.) Ammatillinen koulutus ja yhteiskunnalliset eronteot. Helsinki: Gaudeamus, 236-254.

Eriksson, Susan (2008) Erot, erilaisuus ja elinolot - vammaisten arkielämä ja itsemäärääminen. Helsinki: Kehitysvammaliiton tutkimuksia 3. http://www. kehitysvammaliitto.fi/wp-content/uploads/kehitysvammaliiton-tutkimuksia-3.pdf Luettu 11.1.2018.

Handelskammer Hamburg (2014a) Tipps für Neueinsteiger in die duale Berufsausbildung. Hamburg: Handelskammer Hamburg.

Handelskammer Hamburg (2014b) Aus- und Weiterbildung. Ausbildungsvergütungen - Tarife. Hamburg: Handelskammer Hamburg. http:// www.hk24.de/aus_und_weiterbildung/ ausbildungsberatung/tipps_zur_ausbildung/353868/gV_Ausbildungsverguetung.html Luettu 6.7.2014.

Hensen-Reifgens, Kristina Alice \& Hippach-Schneider, Ute (2014) Germany VET in Europe. Country Report 2014. Bonn, Federal Institute for Vocational Education and Training (BIBB). http://www.refernet.de/media/BIBB_ReferNet_barrierefrei(1). pdf Luettu 9.4.2017.

Irjala, Marja (2014) Tuettu oppisopimuskoulutus - Erityisryhmille mahdollisuus yhdenvertaisuuteen työelämässä. Pro gradu -tutkielma. Kasvatustieteiden yksikkö. Tampere: Tampereen yliopisto.

Irjala, Marja (2017) Osallinen, syrjässä, marginaalissa, onnellinen? Tutkimus oppisopimuskoulutuksen erityisopiskelijoista Suomessa ja Saksassa. Acta Universitatis Ouluensis, E Scientitae Rerum Socialium 173. Oulu: Oulun yliopisto.

Leino, Olavi (2011) Oppisopimusopiskelijan oppimisen henkilökohtaistaminen ja oppimismahdollisuudet työpaikalla. Publications of the University of Eastern Finland Dissertations in Education, Humanities, and Theology No 20. Joensuu: University of Eastern Finland.

Lippegaus-Grünau, Petra (2014) Ausbildung für alle: Die Assistierte Ausbildung bietet Chancen für eine inklusive berufliche Bildung. Die Politische Meinung 59 (525). http://www.kas. de/wf/doc/kas_37463-544-1-30. pdf?140520103632 Luettu 25.11.2017.

Norontaus, Annukka (2016) Oppisopimuskoulutus yritysten tuottamana koulutuspalveluna: tavoitteista vaikutuksiin. Acta Universitatis Lappeenrantaensis 693. Lappeenranta: Lappeenrannan teknillinen yliopisto.

OECD (2010) Vocational education and training in Germany: Strengths, challenges and recommendations. Paris: The Organisation for Economic Cooperation and Development (OECD), Directorate for Education, Education and Training Policy Division. http:// www.oecd.org/education/skills-beyond-school/45938559.pdf Luettu 25.11.2017.

Opetushallitus (2017) Ammattikoulutus. Oppisopimuskoulutus. Lainsäädäntö. http://www.oph.fi/koulutus_ja_tutkinnot/ammattikoulutus/oppisopimuskoulutus/lainsaadanto Luettu 25.11.2017.

Rawls, John (1988) Oikeudenmukaisuusteoria. Helsinki: WSOY.

Saari, Juho (2015) Huono-osaiset: Elämän edellytykset yhteiskunnan pohjalla. Helsinki: Gaudeamus.

Sennett, Richard (2002) Työn uusi järjestys: Miten uusi kapitalismi kuluttaa ihmisen luonnetta. Tampere:Vastapaino. 
Sihvola, Juha (2004) Maailmankansalaisen etiikka. Helsinki: Otava.

Silvennoinen, Heikki (2002) Koulutus marginalisaation hallintana. Helsinki: Gaudeamus.

Sosiaali- ja terveysministeriö (2010) Vahva pohja osallisuudelle ja yhdenvertaisuudelle. Suomen vammaispoliittinen ohjelma VAMPO 2010-2015. Sosiaalija terveysministeriön julkaisuja 2010: 4. Helsinki: Sosiaali- ja terveysministeriö. Sozialgesetzbuch IX \& 71 (2015) Teil 2: Besondere Regelungen zur Teilhabe schwerbehinderter Menschen (Schwerbehindertenrecht). Pflicht der Arbeitgeber zur Beschäftigung schwerbehinderter Menschen.
Vehmas, Simo (2005) Vammaisuus: Johdatus historiaan, teoriaan ja etiikkaan. Helsinki: Gaudeamus.

Young, Irish Marion (1990) Justice and the politics of difference: Introduction. Princeton: Princeton University Press. 